\title{
SISTEM WARALABA DALAM KAIDAH MASKAHAH MURSALAH
}

\author{
Joko Hadi Purnomo \\ Sekolah Tinggi Ilmu Agama Islam Al Hikmah Tuban \\ e-mail: joko.hpurnomo@gmail.com
}

\begin{abstract}
Franchising is a business of cooperation among the parties. One party is called a franchisor and another party is called the franchisee to increase market penetration, growing new businesses and open working opportunity. Masłahłh mursalah is used to address and answer new issues and developments that arise due to the progress of science and modern technology, both in setting the law against new problems, no provision of law and a new law to replace the old laws that do not conform any more with the circumstances, situations, conditions and welfare of the people of today. Maslahth mursalah is one method of istinbat al-hick that is made hitjjah. For examples of problems set by mastahth mursalah ruling, it is shown that laws enacted by the method is more nurturing and more able to realize the sharia objectives, and it is the effectiveness of masbahth mursalah in setting the Islamic rules. Franchise system has a lot of benefit. Although not perfect, but overall it gives any favor by minimizing business risks, taking masłahth and keep madlizah. The franchise system, of course, has been in accordance with the rules of mastahth mursalah.
\end{abstract}

Keywords: franchising, business, masłahłh mursalah

\section{Pendahuluan}

Allah menurunkan hukum Islam sebagai suatu peraturan (syariat) yang dipergunakan untuk kemaslahatan umat manusia agar dapat hidup tenang, damai, tentram dan bahagia baik di dunia maupun di akhirat. Allah dengan rahmat-Nya tidak meninggalkan manusia dalam kegelapan. Dia mengutus para rasul-Nya di berbagai bangsa dan sepanjang waktu untuk menjelaskan dan menunjukkan kepada umat jalan yang makruf dan jalan yang mungkar, yang benar dan yang salah. Semua ajaran secara bertahap dibawa oleh para rasul-Nya saling memperkuat hingga ajaran terakhir yang dibawa oleh Nabi Muhammad. Ajaran-ajaran tersebut berupa aturan dan ketentuan yang akan dipedomani dan diamalkan oleh manusia dalam mencari kebahagiaan. Ajaran itulah yang akan membimbing manusia ke jalan yang benar menuju kepuasan hakiki yang diridai oleh Allah dan Rasul-Nya.

Seluruh upaya dan cara untuk mencapai kepuasan itu adalah masłahłh. Mempertahankan, memelihara dan meningkatkan mutunya juga bagian dari masłahłıh. Dengan demikian, ajaran yang dibawa oleh Nabi Muhammad yang berupa syariat Islam adalah agama yang berorientasi pada kemaslahatan. Masłah dia mendatangkan kedamaian dan kebahagiaan. Seperti yang dijelaskan di dalam al-Quran: 


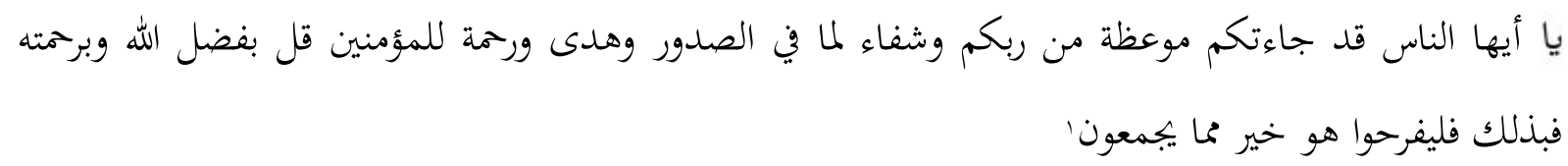

"Hai manusia, sesungguhnya telah datang kepadamu pelajaran dari Tuhanmu dan penyembuh bagi penyakit-penyakit (yang berada) dalam dada dan petunjuk serta rahmat bagi orang-orang yang beriman. Katakanlah dengan kurnia Allah dan rahmat-Nya, hendaklah dengan itu mereka bergembira. Karunia Allah dan rahmat-Nya itu adalah lebih baik dari apa yang mereka kumpulkan".

Dan sesungguhnya ayat di atas mengandung kemaslahatan-kemaslahatan yang begitu besar bagi manusia dalam hidup dan penghidupannya. Maka apabila kita meneliti dan memperhatikan ayat-ayat al-Quran akan ditemukan banya sekali ayat-ayat yang berbicara mengenai pemeliharaan kemaslahatan manusia.

Ketika Nabi Muhammad wafat pada tahun 362 M, beliau telah menyampaikan al-Quran secara keseluruhan dan telah menjelaskan kandungannya sesuai dengan kebutuhan umat pada saat itu. Dengan demikian, cukuplah al-Quran dan Sunnah Nabi Muhammad yang menjadi pegangan masyarakat menyangkut kehidupan keseharian mereka. Akan tetapi, bagi masyarakat yang jauh dari Nabi, tentu situasi demikian merupakan suatu hal yang sulit. Untuk itu, Rasulullah mengizinkan orang yang mempunyai kemampuan berijtihad untuk melakukan ijtihad.

Perubahan menuju perkembangan, banyak menimbulkan permasalahan baru dalam segala bidang, terutama bidang sosial, budaya, sains dan teknologi yang dulunya belum terpikirkan oleh mujtahid-mujtahid kita, sekarang sudah bermunculan. Yusuf Qardhawi mengatakan bahwa kondisi masyarakat selalu berubah dan berkembang, dan selama itu syariat Islam masih cocok di setiap waktu dan tempat serta masih harus menetapkan hukum setiap perkara manusia, terutama zaman sekarang ini, ijtihad lebih dibutuhkan bila dibandingkan zaman sebelumnya."2

Sebagaimana kita ketahui, bahwa pada dasarnya hukum Islam itu hanya bersumber dari al-Quran dan al-Hadis. Namun, setelah Islam semakin berkembang, maka timbullah berbagai macam istilah-istilah dalam penggalian hukum Islam (metode istinba yang dimunculkan oleh para mujtahid, sehingga dikenal lah istilah sebagai hukum primer dan hukum sekunder. Hukum primer yaitu hukum-hukum yang telah disepakati oleh jumhur ulama (al-Quran, Sunnah, ijma $>$ dan qiya $\$$ ), dan sumber hukum sekunder yaitu sumber-sumber hukum yang masih diperselisihkan pemakaiannya dalam menetapkan hukum Islam oleh para ulama (al-

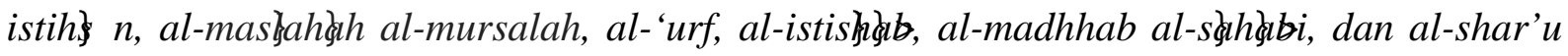
man qablana?.

Salah satu dari sumber hukum sekunder dalam Islam akan dibahas secara lebih detail, yaitu masłahłh mursalah. Secara umum, masłahłh mursalah adalah hukum yang ditetapkan karena tuntutan masłahlgh yang tidak didukung maupun diabaikan oleh dalil khusus, tetapi masih sesuai dengan maqasid shar'iyyah 'ałrmah (tujuan umum hukum Islam).

\footnotetext{
${ }^{1}$ al-Quran, 10: 57-58.

${ }^{2}$ Yusuf al-Qardhawi, Ijtihad dalam Syariat Islam; Beberapa Analisis Tentang Ijtihad Kontemporer (Jakarta: Bulan Bintang), 132.
} 
Masłahłh mursalah merupakan jalan yang ditempuh hukum Islam untuk menerapkan kaidah-kaidah dan perintah-Nya terhadap peristiwa baru yang tidak ada nashnya. Di samping itu, masłahłh mursalah juga menjadi jalan dalam menetapkan aturan yang harus ada dalam perjalanan hidup umat manusia agar sesuai dengan maqasijd shar'iyyah 'a mamah (pemeliharan terhadap agama, jiwa, akal, keturunan dan harta), dan satu perbuatan yang pada intinya untuk memelihara kelima aspek tujuan syara' tersebut, maka dinamakan maslahah. Konsep masłah $\mathrm{t} h$ mursalah tidak hanya terbatas pada masalah ibadah, tetapi juga masalah muamalah. Dan kali ini penulis berusaha menyoroti konsep masłahłh mursalah dari sisi muamalahnya (dalam hal ini ditekankan pada kegiatan bisnis/entrepreneurship).

Berbisnis termasuk dalam kegiatan wirausaha. Jiwa kewirausahaan sebenarnya telah ada pada suri tauladan Nabi Muhammad. Pada waktu beliau masih kecil, Rasul bekerja menjadi seorang pengembala kambing demi menjaga kehormatan dan harga dirinya agar tidak menjadi beban bagi orang lain. Pada saat usia beliau 12 tahun, beliau melakukan perjalanan ke Syiria bersama Abu Thalib, di sinilah beliau banyak belajar mengenai bisnis perdagangan dari pamannya, hingga akhirnya beliau berdagang sendiri ke kota Mekkah demi untuk memberi nafkah keluarga besar pamannya. Aktivitas bisnis kian berlanjut meskipun Rasul tidak memiliki modal sendiri, ternyata beliau mendapatkan modal dari orang-orang kaya di kota Mekkah yang tidak sanggup memutar uangnya, sehingga mereka memberi dana tersebut kepada Rasul untuk dikelola berdasarkan prinsip kemitraan dengan sistem profit sharing (bagi hasil), seperti yang pernah dilakukan Siti Khadijah.

Hubungan kemitraan yang terjadi saat itu sangat sederhana dan dapat dengan mudah dipraktikkan di masyarakat. Namun seiring dengan perkembangan zaman yang semakin hari semakin canggih dan modern, sistem perdagangan menjadi lebih kompleks lagi. Misalnya bisnis dengan sistem e-commerce dan franchising (waralaba) yang pada masa Rasulullah tentu saja tidak ada.

Waralaba merupakan suatu bentuk perikatan di mana salah satu pihak diberikan hak untuk memanfaatkan dan atau menggunakan hak kekayaan intelektual atas penemuan atau ciri khas usaha yang dimiliki pihak lain dengan sistem imbalan berdasarkan persyaratan yang ditetapkan pihak lain tersebut dalam rangka penyediaan dan atau penjualan barang dan jasa di mana pemberi waralaba lazim disebut franchisor dan penerima waralaba disebut franchisee.

Di Indonesia sendiri, waralaba mulai berkembang pada tahun 1950-an dengan munculnya dealer kendaraan bermotor melalui pembelian lisensi (menjadi agen tunggal pemilik merek). Saat ini bisnis waralaba menjamur mulai dari bidang makanan, minuman, kendaraan bermotor, ritel dan lain sebagainya. Sebagai contoh untuk ritel sekarang ada Indomart dan Alfamart. Bidang kendaraan bermotor ada Astra, dan lain sebagainya.

\section{Pengertian Waralaba/Franchise}

Kata "franchise" berasal dari bahasa Perancis kuno yang berarti "bebas". Pada abad pertengahan, franchise diartikan sebagai hak utama atau kebiasaan, saat itu pemerintahan setempat atau lord (gelar kebangsawanan di Inggris biasanya dimiliki oleh tuan tanah setempat) memberikan hak khusus seperti untuk mengoperasikan kapal feri atau untuk berburu tanahnya. Konsep waralaba/franchise berkembang di Jerman sekitar tahun 1840-an. Pada saat itu, mulai diberikan hak khusus untuk menjual minuman. Hal ini merupakan konsep 
awal dari franchising.

Kata "waralaba" merupakan terjemahan bebas dari kata franchise yang pertama kali dikenalkan oleh lembaga pendidikan dan pembinaan menajemen (LPPM) sebagai padanan kata "franchise". Menurut Kamus Besar Bahasa Indonesia, waralaba berasal dari kata "wara" yang berarti lebih atau istimewa "laba" berarti untung. Jadi, waralaba berarti usaha yang memberikan keuntungan lebih atau istimewa. ${ }^{3}$

Menurut Peraturan Pemerintah RI Nomor 16 tahun 1997 tanggal 18 Juni 1997 tentang Waralaba, dikatakan bahwa waralaba adalah perikatan dimana salah satu pihak diberikan hak untuk memanfaatkan dan atau menggunakan hak atas kekayaan intelektual atau penemuan atau ciri khas usaha yang dimiliki pihak lain dengan suatu imbalan berdasarkan persyaratan dan atau penjualan dan atau jasa. ${ }^{4}$

Jadi yang dimaksud waralaba (franchising) adalah bentuk kerjasama di mana pemberi waralaba (franchisor) memberikan izin kepada penerima waralaba (franchisee) untuk menggunakan hak intelektualnya, seperti nama, merk dagang, produk dan jasa serta sistem operasi usahanya. Sebagai timbal baliknya, penerima waralaba membayar suatu jumlah seperti franchisee fee dan royalty fee atau lainnya. ${ }^{5}$

\section{Elemen-Elemen Pokok dalam Bisnis Waralaba/Franchise}

Dari pengertian yang telah dipaparkan di atas, menunjukkan bahwa waralaba/franchise pada dasarnya mengandung elemen-elemen pokok sebagai berikut:

1. Pemberi waralaba (franchisor), yaitu badan usaha atau perorangan yang memberikan hak kepada pihak lain (franchisee) untuk memanfaatkan segala ciri khas usaha dan segala kekayaan intelektual, seperti nama, merk dagang, dan sistem usaha yang dimilikinya.

2. Penerima waralaba (franchisee) adalah badan usaha atau perorangan yang diberikan atau menerima hak untuk memanfaatkan dan menggunakan hak atas kekayaan intelektual atau ciri khas usaha yang dimiliki oleh franchisor.

3. Adanya penyerahan hak-hak secara eksklusif (dalam praktik meliputi berbagai macam hak intelektual) dari franchisor kepada franchisee.

4. Adanya penetapan wilayah tertentu. Franchise area di mana franchisee diberikan hak oleh franchisor untuk beroperasi di wilayah tertentu.

5. Adanya imbal-prestasi dari franchisee kepada franchisor yang berupa franchisee fee, sebagai imbalan atas pemberian hak pemanfaatan dan penggunaan hak intelektual yang di miliki oleh franchisor yang dibayarkan hanya sekali untuk hak yang diperoleh franchisee, biasa disebut juga sebagai one-time fee dan royalty fee merupakan kontribusi fee dari operasional usaha yang dibayarkan oleh franchisee secara periodik kepada franchisor, biasanya secara bulanan dari besarnya omzet penjualan.

6. Adanya standar mutu yang ditetapkan oleh franchisor kepada franchisee, biasanya tertuang dalam buku petunjuk operasional/operating manuals yang berisikan metode dalam bentuk tertulis yang lengkap untuk menjalankan bisnis franchise, serta supervisi

\footnotetext{
${ }^{3}$ Depdiknas, Kamus Besar Bahasa Indonesia (Jakarta: PT. Balai Pustaka, 1994), 12.

${ }^{4}$ Gunawan Widjaja, Seri Hukum Bisnis; Waralaba, cet II (Jakarta: PT. Raja Grafindo Perkasa, 2003 ), 257.

5 Pietra Sarosa, Kiat Praktis Membuka Usaha; Mewaralabakan Usaha Anda (Jakarta: PT. Elex Media Komputindo, 2004), 2.
} 
secara berkala dalam rangka mempertahankan mutu.

7. Adanya bentuk-bentuk pelatihan yang diselenggarakan oleh franchisor guna meningkatkan keterampilan, yaitu pada pelatihan awal maupun pelatihan yang berkesinambungan.

\section{Jenis-Jenis Waralaba/Franchise}

Dalam bentuknya sebagai bisnis, waralaba/franchise memiliki dua jenis kegiatan:

1. Waralaba/franchise produk dan merek dagang.

Waralaba produk dan merek dagang adalah bentuk waralaba yang paling sederhana. Dalam waralaba produk dan merek dagang, pemberi waralaba memberikan hak kepada penerima waralaba untuk menjual produk yang dikembangkan oleh pemberi waralaba yang disertai dengan pemberian izin untuk menggunakan merek dagang milik pemberi waralaba. Pemberian izin penggunan merek dagang tersebut diberikan dalam rangka penjualan produk yang diwaralabakan tersebut. ${ }^{6}$

2. Waralaba/franchise format bisnis.

Waralaba/franchise produk dan merek dagang adalah bentuk waralaba yang paling sederhana. Dalam waralaba produk dan merek dagang, pemberi waralaba memberikan hak kepada penerima waralaba untuk menjual produk yang dikembangkan oleh pemberi waralaba yang disertai dengan pemberian izin untuk menggunakan merek dagang milik pemberi waralaba. Pemberian izin pengguanan merek dagang tersebut diberikan dalam rangka penjualan produk yang diwaralabakan tersebut. ${ }^{7}$

\section{Pengertian dan Macam-Macam al-Maslahdh}

Secara etimologis, term "masłahłh mursalah" terdiri atas dua suku kata, yaitu masłahłh dan mursalah. Masłahł̧h berasal dari kata dengan penambahan "alif" di awalnya, yang secara arti kata berarti "baik", lawan kata dari "buruk" atau "rusak". Ia adalah

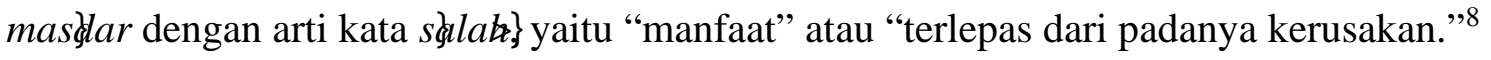

Kata masłahł̧ inipun telah menjadi bahasa Indonesia yang berarti sesuatu yang mendatangkan kebaikan. ${ }^{9}$ Adapun pengertian masłah $\Varangle h$ dalam bahasa Arab berarti perbuatanperbuatan yang mendorong kepada kebaikan manusia. Dalam arti yang umum adalah segala sesuatu yang bermanfaat bagi manusia, baik dalam arti menarik atau menghasilkan, seperti menghasilkan keuntungan atau ketenangan, atau dalam arti menolak atau menghindarkan, seperti menolak kemudharatan atau kerusakan. Jadi, setiap yang mengandung manfaat patut disebut maslahłh. ${ }^{10}$

Sedangkan kata masłahłh merupakan bentuk al-ism al-maf'u內dari kata arsala-yursiluirsabyang artinya 'adam al-taqyiæ (tidak terikat) atau berarti al-mutlaqah (bebas atau lepas). ${ }^{11}$

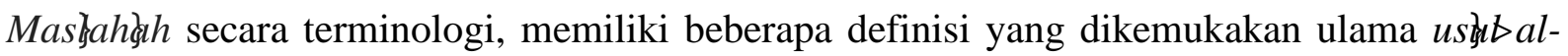

\footnotetext{
${ }^{6}$ Gunawan Widjaja, Seri Hukum Bisnis, 13.

${ }^{7}$ Ibid.

${ }^{8}$ Amir Syarifuddin, Ushul Fiqh, cet I, jilid II (Jakarta: Logos Wacana Ilmu, 1999), 323.

${ }^{9}$ W.J.S. Poerwadarminta, Kamus Umum Bahasa Indonesia (Jakarta: t.p., 1976), 635.

${ }^{10}$ Ibid., 324.

11 Ahmad Mukri Aji, "Pandangan al-Ghazali Tentang Maslahah Mursalah", Jurnal Ahkam, Volume 4, Nomor 8 (2002), 38 .
} 
fiqh, namun secara esensi memiliki definisi yang sama. Imam Ghazali menyatakan masłahł̧ $h$ adalah sesuatu yang mendatangkan manfaat (keuntungan) dan menjauhkan madłtiah (kerusakan), namun hakikat dari masłahłh adalah memelihara tujuan shara', ${ }^{12}$ sekalipun bertentangan dengan tujuan-tujuan manusia, karena kemaslahatan manusia tidak selamanya didasarkan kepada kehendak syariat tetapi sering didasarkan kepada kehendak hawa nafsu, misalnya di zaman jahiliyah para wanita tidak mendapatkan bagian harta warisan yang menurut mereka hal tersebut mengandung kemaslahatan dan sesuai dengan adat istiadat mereka, tetapi pandangan ini tidak sejalan dengan kehendak shara', karenanya tidak dinamakan masłahłh . Oleh sebab itu, menurut Imam al-Ghazali, yang dijadikan patokan dalam menentukan kemaslahatan itu adalah kehendak dan tujuan shara', bukan kehendak dan tujuan manusia. Tujuan shara' yang harus dipelihara tersebut ada lima bentuk, yaitu memelihara agama, jiwa, akal, keturunan dan harta. Apabila seseorang melakukan suatu perbuatan yang pada intinya untuk memelihara kelima aspek tujuan shara' tersebut maka dinamakan masłahłh .

Dalam kaitan dengan ini, al-Syatibi mengartikan masłahł dari segi terjadinya masłahłh dalam kenyataan, dan dari segi tergantungnya tuntutan shara' kepada masłahłh $h$. Dari segi terjadinya masłahł $h$ dalam kenyataan, berarti sesuatu yang kembali kepada tegaknya kehidupan manusia, sempurna hidupnya, tercapai apa yang dikehendaki oleh sifat syahwati dan aklinya secara mutlak. Sedangkan dari segi tergantungnya tuntutan shara' kepada masłahłıh, yaitu kemaslahatan yang merupakan tujuan dari penetapan hukum shara'.

Dari beberapa definisi tentang masłahłh dengan rumusan yang berbeda tersebut, dapat disimpulkan bahwa masłahł̧ itu adalah sesuatu yang dipandang baik oleh akal sehat karena mendatangkan kebaikan dan menghindarkan kerusakan pada manusia, sejalan dengan tujuan shara' dalam menetapkan hukum. Dari kesimpulan tersebut terlihat adanya perbedaan antara masłahł̧ dalam pengertian bahasa (umum) dengan masłahłeh dalam pengertian hukum atau shara'. Perbedaannya terlihat dari segi tujuan shara' yang dijadikan rujukan.

Masłahł̧ dalam pengertian bahasa merujuk kepada tujuan pemenuhan kebutuhan manusia dan karenanya mengandung pengertian untuk mengikuti syahwat dan hawa nafsu.

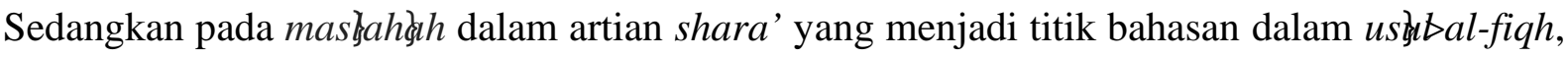
yang selalu menjadi ukuran dan rujukannya adalah tujuan shara', yaitu memelihara agama, akal, keturunan, dan harta benda, tanpa melepaskan tujuan pemenuhan kebutuhan manusia, yaitu mendapatkan kebahagiaan dan menjauhkan dari kesengsaraan.

Pada perkembangan selanjutnya, penggunaan term masłahłh mursalah telah terjadi perbedaan di kalangan ulama us istilah al-munasib al-mursal, al-istidla\al-mursal, al-qiya $>$ al-masłaht. Sedangkan Imam alGhazali menyebutnya dengan nama al-istisbał. $\}^{13}$

\section{Macam-Macam al-Masljhdh}

Masłahłh dalam artian shara' bukan hanya didasarkan pada pertimbangan akal dalam menilai baik buruknya sesuatu, bukan pula dapat mendatangkan kenikmatan dan

\footnotetext{
12 Amir Syarifudin, Ushul Fiqh, 324.

${ }^{13}$ Ahmad Mukri Aji, Pandangan al-Ghazali, 40.
} 
menghindarkan kerusakan, tetapi lebih jauh dari itu, bahwa apa yang dianggap baik oleh akal juga harus sejalan dengan tujuan shara' dalam menetapkan hukum, yaitu memelihara lima prinsip pokok kehidupan.

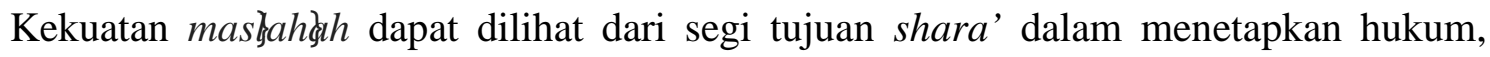
yang berkaitan secara langsung atau tidak langsung dengan lima prinsip pokok kehidupan bagi kehidupan manusia, yaitu agama, jiwa, akal, keturunan dan harta. Juga dapat dilihat dari segi tingkat kebutuhan dan tuntutan kehidupan manusia kepada lima hal tersebut. ${ }^{14}$

Pembagian masłahleh ditinjau dari beberapa bidang, yaitu:

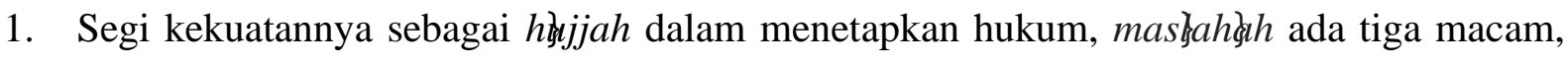
yaitu:

a. Masłahł̧h dłtruxiyyah, adalah kemaslahatan yang keberadaanya sangat dibutuhkan oleh kehidupan manusia. Artinya, kehidupan manusia tidak ada apa-apa bila satu saja dari prinsip yang lima itu tidak ada. Segala usaha yang secara langsung menjamin atau menuju pada keberadaan lima prinsip tersebut adalah baik, atau masłahłh dalam tingkat dels rüri.

b. Masłahłh hłfixyyah, adalah kemaslahatan yang tingkat kehidupan manusia kepadanya

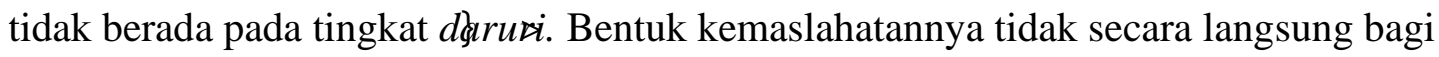
pemenuhan kebutuhan pokok yang lima (dłrüri), tetapi secara tidak langsung menuju ke arah sana, seperti dalam hal yang memberi kemudahan bagi pemenuhan kebutuhan hidup manusia. Seperti dalam bidang ibadah, orang yang sedang sakit atau dalam perjalanan jauh (musafir) dalam bulan Ramadhan diberi keringanan/rukhsłgh oleh syariat untuk tidak berpuasa dengan kewajiban mengganti puasa yang ditinggalkan itu pada hari-hari yang lain setelah ia sembuh atau setelah kembali dari perjalanannya. Firman Allah dalam al-Quran:

$$
\begin{aligned}
& \text { أياما معدودات فمن كان منكم مريضا أو على سفر فعدة من أيام أخر وعلى الذين يطيقونه فدية طعام } \\
& \text { مسكين فمن تطوع خيرا فهو خير له وأن تصوموا خير لكم إن كنتم تعلمون } 10
\end{aligned}
$$

"(yaitu) dalam beberapa hari yang tertentu. Maka barangsiapa diantara kamu ada yang sakit atau dalam perjalanan (lalu ia berbuka), maka (wajiblah baginya berpuasa) sebanyak hari yang ditinggalkan itu pada hari-hari yang lain. Dan wajib bagi orangorang yang berat menjalankannya (jika mereka tidak berpuasa) membayar fidyah, (yaitu): memberi makan seorang miskin. Barangsiapa yang dengan kerelaan hati mengerjakan kebajikan, maka itulah yang lebih baik baginya. Dan berpuasa lebih baik bagimu jika kamu mengetahui”.

Dalam bidang muamalah diperbolehkan berburu binatang dan memakan makanan yang baik-baik, dibolehkan melakukan jual beli pesanan (bay' al-salam), kerjasama dalam pertanian (muzaæa'ah) dan perkebunan (musaæah). Semuanya ini disyariatkan oleh Allah untuk mendukung kebutuhan mendasar al-masłtih lal-khamsah di atas.

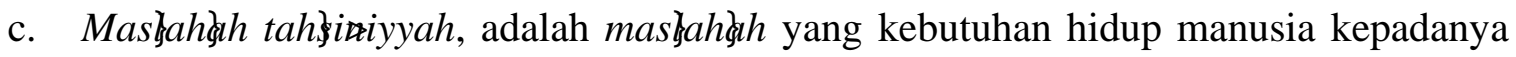

\footnotetext{
${ }^{14}$ Amir Syarifuddin, Ushul Fiqh, 327.

15 al-Quran, 2:184.
} 


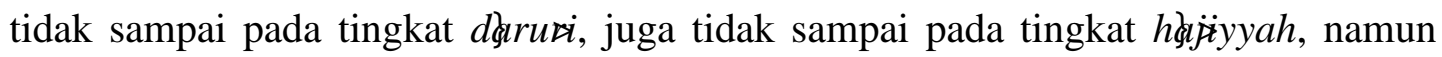
kebutuhan tersebut perlu dipenuhi dalam rangka memberi kesempurnaan dan keindahan bagi hidup manusia. Masłahł̧h dalam bentuk tahłiði tersebut, juga berkaitan dengan lima kebutuhan pokok manusia.

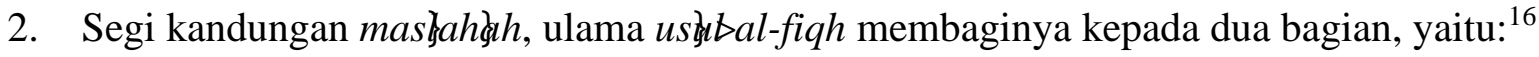

a. Masłahłh 'a mahah, yaitu kemaslahatan umum yang menyangkut kepentingan orang banyak. Kemaslahatan umum itu tidak berarti untuk kepentingan semua orang, tetapi bisa berbentuk kepentingan mayoritas umat.

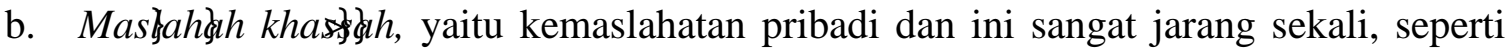
kemaslahatan yang berkaitan dengan pemutusan perkawinan seseorang yang dinyatakan hilang (mafquæ).

3. Segi eksistensinya keberadaan masłahłh menurut shara' terbagi kepada tiga macam, yaitu: $^{17}$

a. Masłahłh mu'tabarah, yaitu kemaslahatan yang terdapat nas\} secara tegas menjelaskan dan mengakui keberadaannya, dengan kata lain kemaslahatan yang diakui shar'i secara tegas dengan dalil yang khusus baik langsung mupun tidak langsung yang memberikan petunjuk pada adanya masłahłh yang menjadi alasan dalam menetapkan hukum. Segi langsung dan tidak langsungnya petunjuk (dalil) terhadap masłah $h_{h} h$ tersebut, masłahł $h$ terbagi dua, yaitu: ${ }^{18}$

1) Munasib mu'aththir, yaitu ada petunjuk langsung dari pembuat hukum (Shaði') yang memperhatikan masłahł̧ $h$ tersebut. Contoh dalil yang menunjuk langsung kepada masłah $\Varangle h$ ialah tidak baiknya "mendekati" perempuan yang sedang haid dengan alasan itu adalah penyakit. Hal ini disebut masłahłh karena menjauhkan diri dari kerusakan atau penyakit. Alasan adanya "penyakit" itu yang dikaitkan dengan larangan mendekati perempuan disebut munasib. Hal ini ditegaskan dalam firman Allah:

$$
\begin{aligned}
& \text { ويسألونك عن المحيض قل هو أذى فاعتزلوا النساء في المحيض ولا تقربوهن حتى يطهرن فإذا تطهرن } \\
& \text { فأتوهن من حيث أمركم الله إن الله يحب التوابين ويحب المتطهرين } 19
\end{aligned}
$$

"Mereka bertanya kepadamu tentang haid. Katakanlah: Haid itu adalah suatu kotoran. Oleh sebab itu hendaklah kamu menjauhkan diri ${ }^{\mathbf{2 0}}$ dari wanita di waktu haid; dan janganlah kamu mendekati mereka, sebelum mereka suci". ${ }^{21}$

2) Munasib mulaæim, yaitu tidak ada petunjuk langsung dari shara', baik dalam bentuk nas\}atau ijma> tentang perhatian shara' terhadap masłahłh tersebut, namun secara tidak langsung ada. Maksudnya, meskipun shara' secara

\footnotetext{
16 Wahidul Kahhar, Efektivitas Maslahah Mursalah dalam Penetapan Hukum Syara (Jakarta: UIN Syarif Hidayatullah, 2003), 23.

${ }^{17}$ Romli SA, Muqaranah Mazahib fil Ushul, cet. I (Jakarta: Gaya Media Pratama, 1999), 162.

18 Amir Syarifuddin, Ushul Fiqh, 329.

19 al-Quraan, 2: 222.

${ }^{20}$ Maksudnya menyetubuhi wanita di waktu haid.

${ }^{21}$ Ialah sesudah mandi. Adapula yang menafsirkan sesudah berhenti darah keluar.
} 
langsung tidak menetapkan suatu keadaan menjadi alasan untuk menetapkan hukum yang disebutkan, namun ada petunjuk shara' bahwa keadaan itulah yang ditetapkan shara' sebagai alasan untuk hukum yang sejenis. Contohnya adalah berlanjutnya perwalian ayah terhadap anak gadisnya dengan alasan anak gadisnya itu belum dewasa. Belum dewasa ini menjadi alasan bagi hukum yang sejenis dengan perwalian dalam harta milik anak kecil.

b. Masłahłh mulghah, yaitu masłahłh yang berlawanan dengan ketentuan nas.\} Dengan kata lain, masłahł̧ yang tertolak karena ada dalil yang menunjukkan bahwa ia bertentangan dengan ketentuan dalil yang jelas. Contoh yang sering diangkat oleh ulama usłt $\triangleright a l$-fiqh adalah menyamakan pembagian harta warisan antara perempuan dengan saudara laki-lakinya. Penyamaan antara seorang perempuan dengan laki-laki tentang warisan memang terlihat ada kemaslahatannya, tetapi berlawanan dengan ketentuan nas yyang jelas dan rinci, sebagaimana firman Allah:

$$
\begin{aligned}
& \text { يوصيكم الله في أولادكم للذكر مثل حظ الأنثين فإن كن نساء فوق اثنتين فلهن ثلثا ما ترك وإن كانت } \\
& \text { واحدة فلها النصف ولأبويه لكل واحد منهما السدس مما ترك إن كان له ولد فإن لم يكن له ولد وورثه } \\
& \text { أبواه فلأمه الثلث فإن كان له إخوة فلأمه السدس من بعد وصية يوصي بها أو دين آباؤكم وأبناؤكم لا } \\
& \text { تدرون أيهم أقرب لكم نفعا فريضة من الله إن الله كان عليما حكيما'r }
\end{aligned}
$$

"Allah mensyariatkan bagimu tentang (pembagian pusaka untuk) anak-anakmu. Yaitu bagian seorang anak lelaki sama dengan bagian dua orang anak perempuan ${ }^{23}$; dan jika anak itu semuanya perempuan lebih dari dua, ${ }^{24}$ maka bagi mereka dua pertiga dari harta yang ditinggalkan. Jika anak perempuan itu seorang saja, maka ia memperoleh separuh harta. Dan untuk dua orang ibu bapak, bagian masing-masing seperenam dari harta yang ditinggalkan, jika yang meninggal itu mempunyai anak. Jika orang yang meninggal tidak mempunyai anak dan ia diwarisi oleh ibu bapaknya (saja), maka ibunya mendapat sepertiga. Jika yang meninggal itu mempunyai beberapa saudara, maka ibunya mendapat seperenam. (Pembagian-pembagian tersebut di atas) sesudah dipenuhi wasiat yang ia buat atau (dan) sesudah dibayar hutangnya. (Tentang) orang tuamu dan anak-anakmu, kamu tidak mengetahui siapa di antara mereka yang lebih dekat (banyak) manfaatnya bagimu. Ini adalah ketetapan dari Allah. Sesungguhnya Allah Maha Mengetahui lagi Maha Bijaksana”.

Ayat ini secara tegas menyebutkan pembagian harta warisan, di mana seorang anak laki-laki sama dengan dua orang anak perempuan. Misalnya sekarang adalah bagaimana jika harta warisan itu dibagi sama rata, intinya seorang anak laki-laki sama bagiannya dengan anak perempuan, dengan alasan ingin menciptakan kemaslahatan. Penyamaan anak laki-laki dengan anak perempuan, dengan kemaslahatan seperti inilah yang disebut dengan al-masłahłh al-mulghah, karena

\footnotetext{
22 al-Quran, 4: 11.

${ }^{23}$ Bagian laki-laki dua kali bagian perempuan adalah karena kewajiban laki-laki lebih berat dari perempuan, seperti kewajiban membayar maskawin dan memberi nafkah.

${ }^{24}$ Lebih dari dua maksudnya adalah dua atau lebih sesuai dengan yang diamalkan Nabi.
} 
bertentangan dengan nas yyang sł̧rite.

c. Masłahłh mursalah, yang juga biasa disebut istisłab,\} yaitu masłahłh yang secara eksplisit tidak ada satu dalil pun, baik yang mengakuinya maupun yang menolaknya. Secara lebih tegas masłahłh mursalah ini termasuk jenis masłahłh yang didiamkan oleh nas\} Masłahłh mursalah ini terus tumbuh dan berkembang seiring dengan perkembangan masyarakat Islam yang dipengaruhi oleh perbedaan kondisi dan tempat.

Ada beberapa rumusan definisi yang berbeda tentang masłahłh mursalah ini, namun masing-masing memiliki kesamaan dan berdekatan pengertiannya. Di antara definisi tersebut adalah: ${ }^{25}$

1) Al-Ghazali dalam kitab al-Mustashfa>merumuskan masłahłh sebagai apa-apa yang tidak ada bukti baginya dari shara' dalam bentuk nas\}tertentu yang membatalkannya dan tidak ada yang memperhatikannya.

2) Abdul Wahab Khallaf memberi rumusan tentang masłahłh mursalah sebagai masłahł menolaknya.

3) Muhammad Abu Zahrah memberi rumusan sebagai masłahłh yang selaras dengan tujuan syariat Islam dan petunjuk tertentu yang membuktikan tentang pengakuannya atau penolakannya.

Dari beberapa rumusan definisi di atas, dapat ditarik kesimpulan tentang hakikat dari masłahłh mursalah tersebut, sebagai berikut:

a) Ia adalah sesuatu yang baik menurut akal dengan pertimbangan dapat mewujudkan kebaikan atau menghindarkan keburukan bagi manusia.

b) Apa yang baik menurut akal itu juga selaras dan sejalan dengan tujuan shara' dalam menetapkan hukum.

c) Apa yang baik menurut akal dan selaras pula dengan tujuan shara' tersebut tidak ada petunjuk shara' secara khusus yang menolaknya, juga tidak ada petunjuk shara' yang mengetahuinya.

\section{Syarat-Syarat al-Masßshdh al-Mursalah}

Ulama dalam memakai dan mempergunakan masłahłh mursalah sebagai hł berhati-hati dan memberikan syarat-syarat yang begitu ketat, karena dikhawatirkan akan menjadi pintu bagi pembentukan hukum syariat menurut hawa nafsu dan keinginan perorangan, bila tidak ada batasan-batasan yang benar dalam memperggunakannya. Adapun syarat-syarat tersebut antara lain: ${ }^{26}$

1. Berupa masłahłhh yang sebenarnya, bukan masłahłhh yang bersifat dugaan. Yang dimaksud dengan ini adalah agar dapat direalisasi pembentukan hukum suatu kejadian itu dan dapat mendatangkan keuntungan, manfaat atau menolak mudarat. Adapun dugaan semata bahwa pembentukan hukum itu mendatangkan keuntungan-keuntungan tanpa pertimbangan di antara masłahł̧ yang dapat didatangkan oleh pembentukan hukum itu,

\footnotetext{
${ }^{25}$ Amir Syarifuddin, Ushul Fiqh, 333.

${ }^{26}$ Abdul Wahab Khallaf, Ilmu Ushul Fiqh (Jakarta: PT. Rineka Citra, 1990), 101. Lihat Amir Syarifuddin, Ushul Fiqh, 337.
} 
maka ini berarti adalah didasarkan atas masłahł ini adalah masłahłh yang didengar dalam hal merampas hak suami untuk menceraikan istrinya dan menjadikan hak menjatuhkan talak itu bagi hakim (qa) keadaan.

2. Berupa masłahłh yang bersifat umum, bukan masłahłh yang bersifat perseorangan. Yang dimaksud dengan ini, yaitu agar dapat direalisasi bahwa dalam pembentukan ukuran suatu kejadian dapat mendatangkan manfaatkan kepada umat manusia, atau dapat menolak mudarat dari mereka dan bukan hanya memberikan manfaat kepada seseorang atau beberapa orang saja. Apabila demikian, maka hal tersebut tidak dapat disyariatkan sebagai sebuah hukum.

3. Pembentukan hukum bagi masłahłh ini tidak bertentangan dengan hukum atau prinsip yang telah ditetapkan oleh nas \}atau ijmas. Dengan kata lain bahwa masłahłh tersebut adalah masłahł th yang hakiki dan selalu berjalan dengan tujuan shara' serta tidak berbenturan dengan dalil-dalil shara' yang telah ada.

4. Masłahłh mursalah itu diamalkan dalam kondisi yang memerlukan, yang seandainya masalahnya tidak diselesaikan dengan cara ini, maka umat akan berada dalam kesulitan hidup, dalam arti harus ditempuh untuk menghindarkan umat dari kesulitan.

Imam Ghazali, dalam mempergunakan pemakaian masłahłh mursalah sebagai salah satu metode penetapan hukum, beliau tidak begitu saja mempergunakannya dengan mudah, namun beliau memakai syarat-syarat yang begitu ketat. Syarat-syarat tersebut antara lain: ${ }^{27}$

1. Masłahłh itu haruslah satu dari lima kebutuhan pokok. Apabila hanya kebutuhan kedua atau pelengkap maka tidak dapat dijadikan landasan.

2. Masłahłth itu haruslah bersifat semesta, yakni kemaslahatan kaum muslimin secara utuh, bukan hanya sebagian orang atau hanya relevan dalam keadaan tertentu.

3. Masłahłh tersebut harus bersifat qat\}i (pasti) atau mendekati itu.

Sedangkan syarat-syarat masłahłh mursalah menurut al-Syatibi adalah sebagai berikut: ${ }^{28}$

1. Masłahłıh itu secara hakiki harus masuk akal.

2. Masłahløh itu harus sejalan dengan tujuan-tujuan umum syariat, tidak bertentangan dengan salah satu prinsip pokok atau dalil qat \}inya.

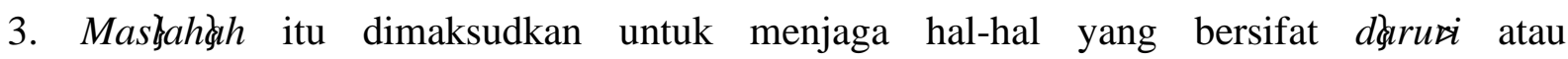
menghilangkan kesulitan dalam agama.

Selanjutnya, Imam Malik juga memiliki versi tersendiri dalam mempergunakan masłahł̧ mursalah sebagai salah satu metode penetapan hukum, syarat-syarat tersebut antara lain: ${ }^{29}$

1. Adanya kesesuaian antara masłahłh yang diperhatikan dengan maqasidd shar'iyyah, dimana masłahłh tersebut tidak bertentangan dengan dasar dan dalil shara' meskipun hanya satu.

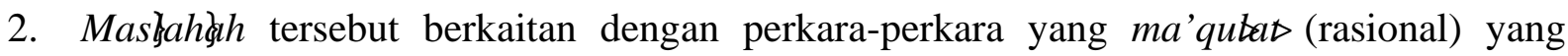

\footnotetext{
${ }^{27}$ Yusuf al-Qardhawi, Keluwesan dan Keluasan Syariat Islam: Dalam Menghadapi Perubahan Zaman, Cet. I (Jakarta: Pustaka Firdaus, Agustus, 1996), 24.

${ }^{28}$ Ibid., 26.

${ }^{29}$ Wahidul Kahhar, Efektivitas Maslahah Mursalah, 36.
} 
menurut shara' didasarkan kepada pemeliharaan terhadap masłahł tempat untuk masłahłh dalam masalah ta'abbudiyyah dan perkara-perkara shara' yang sejenis.

3. Hasil dari masłahł̧ mursalah dikembalikan kepada pemeliharaan terhadap perkara yang dérutri (primer) menurut shara' dan meniadakan kesempitan dalam agama.

Bila kita perhatikan persyaratan di atas, terlihat bahwa ulama yang memakai dan menggunakan masłahłh mursalah dalam berhłjjjah cukup berhati-hati dalam menggunakannya, karena meski bagaimanapun juga apa yang dilakukan ulama ini adalah keberanian menetapkan dalam hal-hal yang pada waktu itu tidak ditemukan petunjuk hukum.

\section{Pendapat Para Ulama Tentang al-Maslshdh al-Mursalah}

Dalam hal penggunaan dan pemakaian masłahłh mursalah sebagai dalil syariat dalam mengistinba an atau menetapkan hukum, maka penulis akan memaparkan pendapat para ulama yang dibatasi pada pendapat beberapa imam mazhab dan ulama terkenal lainnya.

1. Masłahłh menurut Hasbi ash-Shiddieqy

Menurut Hasbi ash-Shiddieqy, tidak ada perselisihan di kalangan ulama bahwa penetapan-penetapan hukum (tashri ${ }^{*}$ ) dimaksudkan untuk melahirkan kemaslahatan

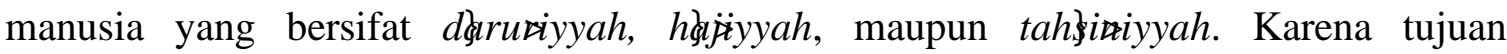
memberikan kemaslahatan itulah, maka ada bagian dalam fikih yang dinamakan siyasah shar'iyyah, yakni kebijaksanaan untuk membuat masyarakat lebih dekat dan gemar kepada kebajikan serta menjauhi dan membenci keburukan dan kerusakan.

Menurut Hasbi, siyasah shar'iyyah pada hakikatnya sama dengan masłahłh mursalah. Masłahlth mursalah inilah yang digali melalui qiyas, kaidah umum hukum dan istihła Selain itu, mayoritas ulama pun sepakat, bahwa yang dinaskan oleh shara’ yang didasarkan atas 'illat tujuannya adalah untuk mewujudkan kemaslahatan bagi manusia. Hasbi berpendapat bahwa berhłłjjah dengan masłahłh mursalah dan membina hukum di atasnya adalah satu keharusan. Inilah yang sesuai dengan keumuman syariat. Dan dengan demikianlah hukum-hukum Islam dapat berjalan seiringan dengan masa, dan inilah yang ditempuh oleh para sahabat. Menolak masłahłh mursalah berarti membekukan syariat, karena aneka masłah $₫ h$ yang terus tumbuh tidak mudah didasarkan pada satu dalil tertentu". 30

2. Masłahł $h$ menurut Mazhab Maliki, Hambali dan al-Syathibi

Ulama Malikiyah dan Hanabilah menerima masłahłh mursalah sebagai dalil dalam menetapkan hukum, bahkan mereka dianggap sebagai ulama fikih yang paling banyak dan luas menerapkannya. Menurut mereka, masłahłı mursalah merupakan induksi dari logika sekumpulan nas\} bukan dari nas\}yang dirinci seperti yang berlaku dalam qiyas. Bahkan Imam al-Syathibi mengatakan bahwa keberadaan dan kualitas masłahłıh mursalah bersifat pasti (qat\}i), sekalipun dalam penerapannya bisa bersifat żłnni (relatif). ${ }^{31}$

3. Masłahłh menurut Najmuddin at-Thufi

\footnotetext{
${ }^{30}$ Ibid., 69.

${ }^{31}$ Harun Nasroen, Ushul Fiqh, cet. 3 (Jakarta: Logos Wacana Ilmu, 2001), 125-126.
} 
Menurut beliau, masłahł̧h merupakan hłjjjah terkuat yang secara mandiri dapat dijadikan sebagai landasan hukum. Ia tidak membagi masłahłh itu sebagaimana yang dilakukan oleh mayoritas ulama. Ada tiga prinsip yang dianut al-Thufi tentang masłahlıh yang menyebabkan pandangannya berbeda dengan mayoritas ulama, yaitu: ${ }^{32}$

a. Akal bebas menentukan kemaslahatan dan kemafsadatan khususnya dalam bidang muamalah dan adat. Untuk menentukan kemaslahatan dan kemudharataan cukup dengan akal. Pandangan ini berbeda dengan jumhur ulama yang mengatakan bahwa sekalipun kemaslahatan dan kemudharatan itu dapat dicapai dengan akal, namun kemaslahatan itu harus mendapatkan dukungan dari nas \}atau ijma $>$ baik bentuk, sifat maupun jenisnya.

b. Masłahłh merupakan dalil mandiri dalam menetapkan hukum. Oleh sebab itu, untuk kehłjjjahan masłahłth tidak diperlukan dalil pendukung, karena masłahłh itu didasarkan kepada pendapat akal semata.

c. Masłahłh hanya berlaku dalam masalah muamalah dan adat kebiasaan. Adapun dalam masalah ibadah atau ukuran-ukuran yang ditetapkan shara', seperti salat zuhur empat rakaat, puasa satu bulan selama bulan Ramadhan dan lain-lain tidak termasuk objek masłahł $h$, karena masalah-masalah seperti ini merupakan hak Allah semata.

\section{Maslyhdh Mursalah dan Sistem Waralaba/Franchise}

Penalaran ijtihad yang menggunakan corak masłahłh mursalah atas dasar bahwa kemaslahatan yang tidak diakui dan juga tidak ditolak keberadaannya ini banyak terjadi dalam masyarakat. Sehingga seorang mujtahid dituntut untuk menyelesaikan persoalan sebagai upaya pengembangan hukum. Masłahłh mursalah diakui jika berkaitan dengan maqasidd shar'iyyah seperti syarat yang ditetapkan oleh Ghazali, yaitu bahwa harus ada kesesuaian antara keduanya, masłah $\Varangle h$ itu harus logis dan bertujuan menghilangkan kesulitan umat manusia.

Kaidah uslł $\triangleright$ al-fiqh yang membolehkan prosedur dan aplikasi waralaba ini, yaitu:

$$
\text { الأصل في المعاملات الإباحة إلا أن يدل دليل على تحيمها }
$$

"Asal dalam akad dan muamalah adalah boleh sehingga ada dalil yang melarang dan mengharamkannya." 33

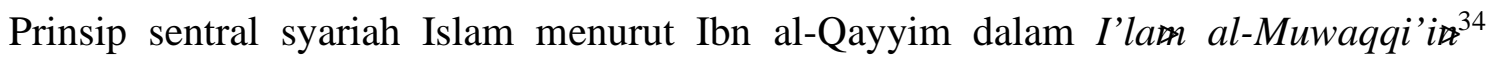
adalah hikmah dan kemaslahatan umat manusia di dunia dan di akhirat. Kemaslahatan ini terletak pada keadilan yang merata, rahmat (kasih sayang dan kepedulian), kesejahteraan dan kebijaksanaan. Apa saja yang mengubah keadilan menjadi kezaliman, rahmat menjadi kekerasan, kemudahan menjadi kesulitan, dan hikmah menjadi kebodohan, maka hal itu tidak ada kaitannya dengan syariah.

Waralaba dalam prakteknya memberikan berbagai keuntungan, baik dari sisi penerima waralaba (franchisee) maupun pemberi waralaba (franchisor). Keuntungan franchisee di

\footnotetext{
${ }^{32}$ Ibid., 126-127.

${ }^{33}$ Ibn Rusyd, Tarjamah Bidayatul Mujtahid, cet. 1 (Semarang: Asy-syifa, t.th.) 52.

${ }^{34}$ Setiawan Budi Utomo, Fiqh Aktual Jawaban Tuntas Masalah Kontemporer (Jakarta: GIP, 2003), 52.
} 
antaranya adalah langsung memiliki sistem yang mapan (established business), produk dan jasa yang memiliki reputasi karena produk telah dikenal oleh masyarakat secara luas, produk sudah dikenal konsumen. Sedangkan keuntungan dari franchisor adalah perusahaan dapat melakukan efisiensi perluasan perusahaan, karena modal, sumber daya manusia telah disiapkan oleh franchisee. Franchisor dapat melakukan perluasan (dan penetrasi) pasar secara cepat, karena ada dukungan yang diberikan oleh franchisee.

Waralaba juga memberikan keuntungan bagi pengusaha pemula yang awam bisnis untuk memulai bisnis dengan lebih terukur dan tidak gambling, karena franchisor telah memiliki sistem manajemen pengelolaan usaha yang secara keseluruhan telah teruji. Dengan sistem yang teruji, resiko kerugian dari pengusaha dapat pula ditekan sehingga sebagaimana dalam prinsip bisnis dalam ekonomi syariah adalah menghindarkan maysi $\gg$, yakni melakukan aktivitas ekonomi secara membabi buta, tanpa mengetahui apakah bisnis ini menguntungkan atau merugikannya.

Sistem waralaba memberikan peluang bagi tersedianya lapangan pekerjaan baru. Dengan demikian dapat mengurangi dan mengatasi pengangguran. Adanya pengangguran berpotensi terjadinya kriminalitas yang akan menganggu kehidupan bermasyarakat suatu bangsa. Sistem waralaba sejalan dengan tujuan utama ketentuan syariah yang tercermin dalam pemeliharaan pilar-pilar kesejahteraan umat manusia yang mencakup lima maslahat dengan memberikan perlindungan terhadap aspek keimanan, kehidupan, akal, keturunan dan harta benda.

Waralaba sejalan dengan sistem nilai syariah sebagai filter moral bisnis bertujuan untuk menghindari berbagai penyimpangan moral bisnis (moral hazard) dengan komitmen menjauhi pantangan maghrib. ${ }^{35}$ Termasuk dalam kegiatan usaha waralaba yang menjadi parameter berlakunya kaidah al-asłu fi al-mua'a ralah al-ibaty yang meliputi tujuh pantangan sebagai berikut:

1. Maysi $\gg$. Segala bentuk spekulasi judi (gambling) yang mematikan sektor riil dan tidak produktif.

2. Asusila. Praktik usaha yang melanggar kesusilaan dan norma sosial.

3. Ghara . Segala transaksi yang tidak transparan dan tidak jelas sehingga berpotensi merugikan salah satu pihak.

4. Haram. Objek transaksi dan proyek usaha yang diharamkan syariah.

5. Riba. Segala bentuk distorsi mata uang menjadi komoditas dengan mengenakan tambahan (bunga) pada transaksi kredit atau pinjaman dan pertukaran atau barter lebih antar barang ribawi sejenis. Pelarangan riba ini mendorong usaha yang berbasis kemitraan yang saling menguntungkan dan kenormalan (sunnah Allah) bisnis, disamping menghindari praktik pemerasan, eksploitasi dan penzaliman oleh pihak yang memiliki posisi tawar tinggi terhadap pihak yang berposisi tawar rendah.

6. Ihtika P. Penimbunan dan monopoli barang dan jasa untuk tujuan permainan harga.

7. Berbahaya. Segala bentuk transaksi dan usaha yang membahayakan individu maupun masyarakat serta bertentangan dengan maslahat dalam maqasid shar'iyyah.

Waralaba juga memegang prinsip keterbukaan, kejujuran. Kedua prinsip tersebut merupakan kunci utama orang melakukan bisnis. Hal itu sejalan dengan firman Allah:

\footnotetext{
${ }^{35}$ Ibid.
} 


$$
\begin{aligned}
& \text { يا أيها الذين آمنوا لا تحلوا شعائر الله ولا الشهر الحرام ولا الهدي ولا القلائد ولا آمين البيت الحرام يبتغون فضلا } \\
& \text { من ربهم ورضوانا وإذا حللتم فاصطادوا ولا يجرمنكم شنآن قوم أن صدوكم عن المسجد الحرام أن تعتدوا وتعاونوا } \\
& \text { على البر والتقوى ولا تعاونوا على الإثم والعدوان واتقوا الله إن الله شديد العقاب بـr }
\end{aligned}
$$

"Hai orang-orang yang beriman, janganlah kamu melanggar syiar-syiar Allah, ${ }^{37}$ dan jangan melanggar kehormatan bulan-bulan haram, ${ }^{38}$ jangan (mengganggu) binatangbinatang $h \not d d-\mathrm{Nya}^{39}{ }^{39}$ dan binatang-binatang qala d, ${ }^{40}$ dan jangan (pula) mengganggu orang-orang yang mengunjungi Baitullah sedang mereka mencari karunia dan keridaan dari Tuhannya. ${ }^{41}$ Dan apabila kamu telah menyelesaikan ibadah haji, maka bolehlah berburu. Dan janganlah sekali-kali kebencian(mu) kepada sesuatu kaum karena mereka menghalang-halangi kamu dari Masjidil Haram, mendorongmu berbuat aniaya (kepada mereka). Dan tolong-menolonglah kamu dalam (mengerjakan) kebajikan dan takwa, dan jangan tolong-menolong dalam berbuat dosa dan pelanggaran. Dan bertakwalah kamu kepada Allah, sesungguhnya Allah amat berat siksa-Nya".

Waralaba sejalan dengan upaya tolong menolong dalam kebaikan, sebagaimana dijelaskan di atas, bahwa antara franchesee dan franchisor saling menerima manfaat, hal itu sejalan dengan hadis Nabi Muhammad:

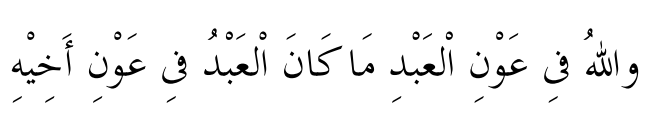

"Dan Allah menolong hamba selama hamba menolong saudaranya".

Jadi sistem waralaba sejalan dengan prinsip-prinsip syariah sebagaimana kaidah masłahłh mursalah.

\section{Kesimpulan}

Waralaba merupakan bisnis kerjasama antara para pihak, satu pihak disebut pemberi waralaba (franchisor) dengan pihak yang lain disebut penerima waralaba (franchisee) untuk meningkatkan penetrasi pasar, menumbuhkan pengusaha baru dan membuka lapangan. Masłahłh mursalah digunakan untuk menyikapi dan menjawab permasalahan-permasalahan dan perkembangan baru yang muncul karena kemajuan ilmu pengetahuan dan teknologi modern, baik dalam menetapkan hukum terhadap masalah-masalah baru dan belum ada ketentuan hukumnya, maupun menetapkan hukum baru untuk menggantikan ketentuan hukum lama yang tidak sesuai lagi dengan keadaan, situasi, kondisi dan kemaslahatan manusia zaman sekarang. Masłahłh mursalah merupakan salah satu metode istinba łhukum

\footnotetext{
36 al-Quran, 5: 2.

${ }^{37}$ Syiar Allah ialah segala amalan yang dilakukan dalam rangka ibadat haji dan tempat-tempat mengerjakannya.

${ }^{38}$ Arti bulan haram adalah dilarang melakukan peperangan di bulan-bulan itu.

${ }^{39}$ Yaitu binatang (unta, lembu, kambing, biri-biri) yang dibawa ke Ka'bah untuk mendekatkan diri kepada Allah, disembelih ditanah haram dan dagingnya dihadiahkan kepada fakir miskin dalam rangka ibadah haji.

${ }^{40}$ Yaitu binatang $h \nmid d$-Nya yang diberi kalung, supaya diketahui orang bahwa binatang itu telah diperuntukkan untuk dibawa ke Ka'bah.

${ }^{41}$ Dimaksud dengan karunia adalah keuntungan yang diberikan Allah dalam perniagaan. Keridaan dari Allah adalah pahala amalan haji.
} 
yang dijadikan hitjjah. Dan dari contoh masalah-masalah yang ditetapkan hukumnya dengan masłahłh mursalah, terlihat bahwa hukum yang ditetapkan dengan metode tersebut lebih mengayomi dan lebih mampu merealisasikan tujuan-tujuan syariat, dan di sini pula lah letak keefektifan masłahłh mursalah dalam penetapan hukum shara'.

Sistem waralaba memiliki banyak kemaslahatan. Walaupun tidak sempurna, akan tetapi secara keseluruhan memberikan kebaikan dengan meminimalisasi segala risiko usaha, mengambil masłahłh dan menjauhkan madłıah. Jadi tentu saja sistem waralaba telah sesuai dengan kaidah masłahłh mursalah.

\section{Daftar Rujukan}

al-Qardhawi, Yusuf. Ijtihad Dalam Syariat Islam; Beberapa Analisis Tentang Ijtihad Kontemporer. Jakarta: Bulan Bintang, t.t.

Keluwesan dan Keluasan Syariat Islam dalam Menghadapi Perubahan Zaman, cet. I. Jakarta: Pustaka Firdaus, Agustus, 1996.

Aji, Ahmad Mukri. "Pandangan al-Ghazali Tentang Maslahah Mursalah", Jurnal Ahkam, Volume 4, Nomor 8 (2002).

Ardian, Agnes Vira. "Prospek Perlindungan Hukum Hak Kekayaan Intelektual dalam Kesenian Tradisional di Indonesia”. Tesis--Universitas Diponegoro Semarang, 2008.

Djubaedillah, M. Djumhana R. Hak Kekayaan Intelektual: Sejarah, Teori dan Prakteknya di Indonesia. Jakarta: Citra Aditya Abadi, 2003.

Hariyanti, Iswi. Prosedur Mengurus HAKI yang Benar. Yogyakarta: Pustaka Yustisia, 2010.

Kahhar, Wahidul. Efektivitas Maslahah Mursalah dalam Penetapan Hukum Syara. Jakarta: UIN Syarif Hidayatullah, 2003.

Khallaf, Abdul Wahab. Ilmu Ushul Fiqh. Jakarta: PT. Rineka Citra, 1990.

Departemen Pendidikan Nasional. Kamus Besar Bahasa Indonesia. Jakarta: PT. Balai Pustaka, 1994.

Nasroen, Harun. Ushul Fiqh, cet. III. Jakarta: Logos Wacana Ilmu, 2001.

Poerwadarminta, W.J.S. Kamus Umum Bahasa Indonesia. Jakarta: t.p., 1976.

Romli SA. Muqaranah Mazahib fil Ushul, cet. I. Jakarta: Gaya Media Pratama, 1999.

Rusyd, Ibn. Tarjamah Bidayatul Mujtahid, cet. I. Semarang: asy-Syifa, 1990.

Sarosa, Pietra. Kiat Praktis Membuka Usaha; Mewaralabakan Usaha Anda. Jakarta: PT. Elex Media Komputindo, 2004.

Syarifuddin, Amir. Ushul Fiqh, cet. 1, Jilid 2. Jakarta: Logos Wacana Ilmu, 1999.

Utomo, Setiawan Budi. Fiqh Aktual Jawaban Tuntas Masalah Kontemporer. Jakarta: GIP, 2003.

Widjaja, Gunawan. Seri Hukum Bisnis; Waralaba, cet. 2. Jakarta: PT. Raja Grafindo Perkasa, 2003. 